\title{
Intestinal pseudo-obstruction: An important diagnostic challenge
}

\section{Carmen Salvador Coloma', Mohamed Hassan Bennis², Lydia Díez Langhetée³, Óscar Niño Gómez', Encarnación Reche Santos ${ }^{1}$, Óscar Juan Vidal ${ }^{1}$}

\author{
${ }^{I}$ Department of Medical Oncology, Hospital Universitari i Politècnic La Fe, Valencia, Spain \\ ${ }^{2}$ Department of Medical Oncology, Hospital de Xativa, Valencia, Spain \\ ${ }^{3}$ Department of Internal Medicine, Hospital Universitari i Politècnic La Fe, Valencia, Spain
}

Received April 12, 2015; Revised May 12, 2015; Accepted May 17, 2015; Published Online June 09, 2015

\section{Case Report}

\begin{abstract}
We present the case of a 72-year-old patient admitted on various occasions with symptoms of intestinal pseudo-obstruction. Extensive diagnostic tests eventually found that the patient had small-cell lung cancer associated with high anti-HU antibody titres, which pointed to a probable paraneoplastic intestinal obstruction syndrome associated with small-cell lung cancer. A paraneoplastic syndrome causing abnormal changes in gastrointestinal motility can be the first signs of small cell lung cancer. These syndromes improve with treatment of the underlying disease, as seen in our patient, who stopped having episodes of intestinal pseudo-obstruction after administration of chemotherapy.
\end{abstract}

Keywords: Lung Cancer; Small-Cell Lung Cancer; Anti-HU; Paraneoplastic Syndrome; Intestinal Obstruction

\section{Introduction}

A 72-year-old patient with a number of cardiovascular risk factors (hypertension, diabetes, dyslipidaemia, obesity and smoking, with a history of 120 pack-years) and chronic obstructive pulmonary disease on treatment with insulin, antihypertensive drugs, lipid-lowering drugs and bronchodilators.

He came to Accident and Emergency Department with a three-day history of nausea, vomiting, intolerance of oral diet and generalised abdominal pain associated with not having passed wind or moved his bowels for eight days.

The patient's general condition was fair. Haemodynamically was stable. Heart and lung sounds were normal. Abdomen was distended. Tympanic percussion was observed. No bowel sounds were detected. Diffuse pain on abdominal palpation was observed. No relevant findings on rectal examination and the rest of examination were found.

Additional tests were done: normal blood test results except creatinine $1.53 \mathrm{mg} / \mathrm{dl}$; Urea $71 \mathrm{mg} / \mathrm{dl}$; CRP $89 \mathrm{mg} / \mathrm{l}$; transaminases and bilirubin within normal limits; haemoglobin $11.2 \mathrm{~g} / \mathrm{dl}$; MCV $74 \mathrm{fl}$; MCH $22.9 \mathrm{pg}$; Leucocytes $10.2 \times 10^{3}$ per ul (differential normal); Quick's Test 72\%. The X-ray Abdomen showed small bowel loops greatly dilated and no gas observed in colon, even distally. Erect, there areair-fluid levels and more than three levels. Images suggestive of small bowel obstruction (Figure 1). The CT Abdomen-Pelvis scan manifested a distension of stomach and jejunum as far as right iliac fossa, where change in lumen visible although with no evidence of obstructive cause. No other relevant findings (Figure 2).

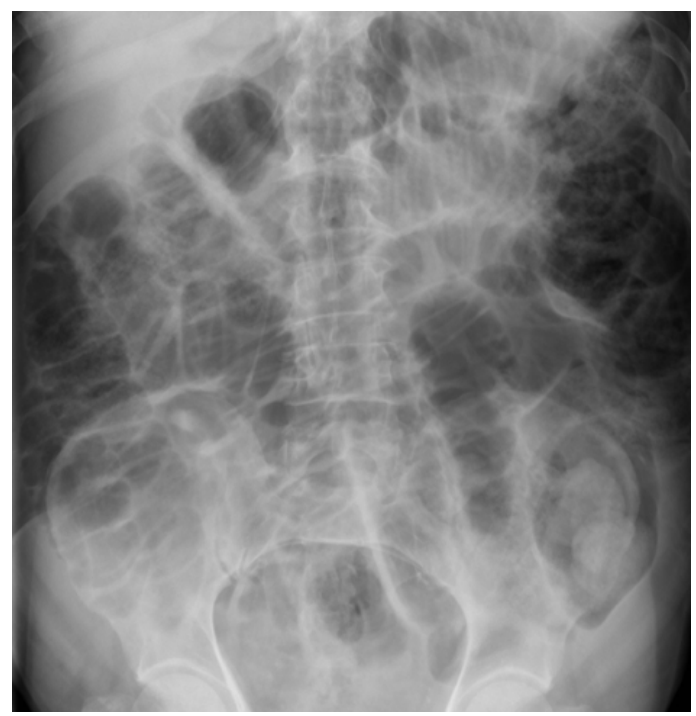

FIG. 1: Image suggestive of small bowel obstruction. 

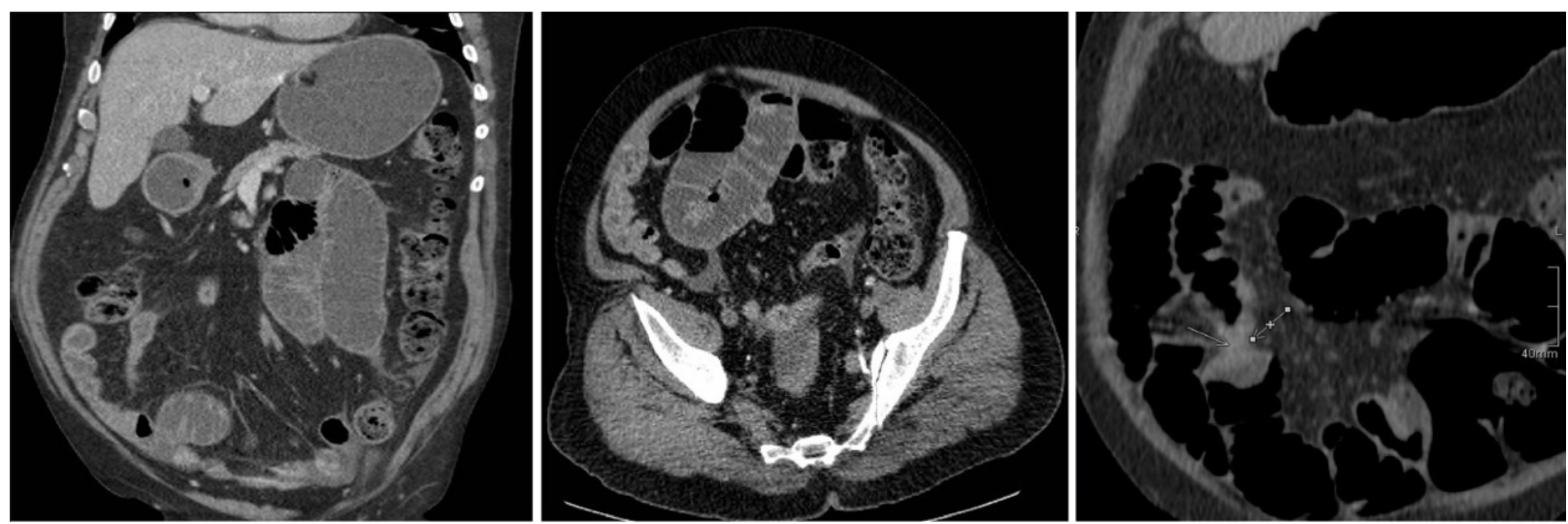

FIG. 2: Distension of stomach and jejunum as far as right iliac fossa, where change in lumen visible although with no evidence of obstructive cause.

TABLE 1: Intestinal pseudo-obstruction causes.

\begin{tabular}{|c|c|c|c|c|c|c|c|c|}
\hline $\begin{array}{l}\text { Auto- } \\
\text { immune } \\
\text { diseases }\end{array}$ & $\begin{array}{l}\text { Infectious } \\
\text { diseases }\end{array}$ & Endocrine diseases & $\begin{array}{l}\text { Neurological } \\
\text { diseases }\end{array}$ & $\begin{array}{l}\text { Oncological } \\
\text { disease }\end{array}$ & Myopathy & $\begin{array}{l}\text { Granuloma- } \\
\text { tous diseases }\end{array}$ & Drugs & Other causes \\
\hline $\mathrm{LES}^{\mathrm{a}}$ & HIV & $\begin{array}{l}\text { Hypo- parathy- } \\
\text { roidism }\end{array}$ & D.Ng & $\begin{array}{l}\text { Pheo-chromo } \\
\text { cytoma }\end{array}$ & $\mathrm{MM}^{\mathrm{i}}$ & Tuberculosis & $\begin{array}{l}\text { Anti- depres- } \\
\text { sants }\end{array}$ & Ehlers-Danlos \\
\hline $\begin{array}{l}\text { Crohn } \\
\text { disease }\end{array}$ & $\mathrm{CMV}^{\mathrm{d}}$ & Hypo- thyroidism & Stroke & $\begin{array}{l}\text { Multiple } \\
\text { Myeloma }\end{array}$ & Duchenne & Sarcoidosis & $\begin{array}{l}\text { Anti- } \\
\text { parkisonian }\end{array}$ & Radiation enteritis \\
\hline $\begin{array}{l}\text { Celiac } \\
\text { disease }\end{array}$ & $\mathrm{VZV}^{\mathrm{e}}$ & Hyper- thyroidism & M.S & & M.D ${ }^{\mathrm{k}}$ & Wegener & Vincristine & $\begin{array}{l}\text { eosinophilic gas- } \\
\text { troenteritis }\end{array}$ \\
\hline $\begin{array}{l}\text { Sclero- } \\
\text { derma }\end{array}$ & $\mathrm{VEB}^{\mathrm{f}}$ & & $\begin{array}{l}\text { Parane- } \\
\text { oplastic }\end{array}$ & & $\mathrm{DOF}^{1}$ & $\begin{array}{l}\text { Churg } \\
\text { Strauss }\end{array}$ & Diltiazem & $\begin{array}{l}\text { lymphoid infiltra- } \\
\text { tion }\end{array}$ \\
\hline $\mathrm{DM}^{\mathrm{b}}$ & Kawasaki & & SC injury ${ }^{\mathrm{i}}$ & & & & Nifedipine & sickle-cell anemia \\
\hline & Chagas & & $\begin{array}{l}\text { Amyloidosis } \\
\text { Parkinson }\end{array}$ & & & & Narcotics & Diverticulosis \\
\hline
\end{tabular}

Abbreviations: ${ }^{a}$ LES: Systemic lupus erythematosus, ${ }^{b} \mathrm{DM}$ : Diabetes mellitus, ${ }^{\mathrm{c}} \mathrm{HIV}$ : Human immunodeficiency virus, ${ }^{\mathrm{d} C M V}$ : Cytomegalovirus, ${ }^{\mathrm{e} V Z V}$ : Varicella zoster, ${ }^{\text {fVEB}}$ : Epstein barr virus, ${ }^{\mathrm{g}}$ D.N: Diabetic neuropathy, ${ }^{\mathrm{h}} \mathrm{M} . \mathrm{S}$ : Multiple sclerosis, ${ }^{\mathrm{i}}$ spinal cord injury, ${ }^{\mathrm{j} M M}$ : Mitochondrial myopathy, ${ }^{k}$ M.D: Myotonic dystrophy, ${ }^{1}$ oculopharyngeal dystrophy.

In view of the above, an exploratory laparotomy was performed, but no obstructive component was found, only a dilation of small bowel loops from the ligament of Treitz to the terminal ileum with dilation of the caecum without signs of obstructive cause. Following the intervention, the patient was transferred to the Recovery Unit and once he had sufficiently recovered, a CT scan of the chest/abdomen/pelvis was ordered which showed lymphadenopathy-type mediastinal masses in virtually all the node spaces, in addition to ischaemia with pneumatosis intestinalis in the caecum and part of the ascending colon, along with pneumoperitoneum, which was possibly secondary to microperforation. The patient was eventually discharged once normal bowel function was restored, with conservative treatment and follow-up at Respiratory Medicine Outpatients.

Two weeks after being discharged, the patient had a further episode of abdominal pain, vomiting and diarrhoea lasting a week, with deterioration in his general condition, and had to be re-admitted. Suspecting dysentery, tests were ordered for rotavirus and adenovirus antigens, clostridium toxin, parasites in faeces, stool cultures and human immunodeficiency virus (HIV) serology, all of which were negative. A drug-related cause was ruled out. The symptoms were not suggestive of either food poisoning or food allergy. Thyroid hormones and transglutaminase antibodies were normal. A colonoscopy was performed showing ulceration of the right colon/caecum; biopsies were taken but results came back as normal. Having made good progress, the patient was discharged with the diagnosis of suspected ischemic colitis and an appointment for follow-up at Gastrointestinal Medicine Outpatients.

Over the following four weeks, he was admitted on two more occasions for partial obstruction which, like the previous episodes, simulated intestinal obstruction but in the absence of any anatomical obstruction. The main causes of intestinal pseudo-obstruction were ruled out (Table 1): autoimmune (for not meeting criteria; ANAs, ENAs, ANCAs negative; absence of skin manifestations and normal colonoscopy), endocrine-metabolic (hormones negative), myopathy (biopsy negative), infectious causes (serology negative).

At the end of this process, the differential diagnosis was between granulomatous, neurological and oncological diseases. We then ordered a positron-emission tomography (PET) 
scan, endobronchial ultrasound (EBUS) with bronchoalveolar lavage, electromyogram (EMG), anti-HU antibodies, Mantoux test and tumour markers. The PET showed abnormal uptake in a number of different lymph node regions with SUV (standardized uptake value) ranging from 4.8 to 11.3. The Mantoux test was negative and tumour markers and angiotensin-converting enzyme (ECA) were normal.

The pathology results were compatible with small cell lung cancer. At the same time, the lymph node samples were subjected to flow cytometry analysis, ruling out lymph node cell proliferation.

With the diagnosis of small cell lung cancer with disease limited to the thorax, the patient was started on cisplatin/etoposide-based chemotherapy with concomitant radiotherapy. We received the positive anti-HU anti-neuronal antibody results after starting the treatment.

After five cycles of chemotherapy, the patient's general condition is good and he has had no further admissions for new episodes of partial bowel obstruction.

\section{Discussion}

A paraneoplastic syndrome causing abnormal changes in gastrointestinal motility can be the first signs of small cell lung cancer. ${ }^{2,3}$

Paraneoplastic syndromes can affect any organ or tissue, including both the central nervous system (CNS) and the peripheral nervous system. The latter type occurs in less than $1 \%$ of all cancer patients. The cause of the majority of paraneoplastic neurological syndromes is unknown, but it is thought that the pathogenesis is immune-mediated due to fact that the expression of neuronal antigens by the tumour triggers an immune response against it and the immune response, in turn, affects the nervous system. ${ }^{3,4}$

Paraneoplastic autonomic neuropathy normally occurs as a component of other disorders, but it is very rare for it to be the predominant sign. ${ }^{1}$ These patients may develop life-threatening complications such as gastrointestinal paresis, cardiac arrhythmias and postural hypotension. They are frequently associated with small cell lung cancer (SCLC), cancer of the pancreas, carcinoid tumours and lymphoma.

Anti-HU antibodies are seen in single or multiple (combined forms) paraneoplastic syndromes, such as sensory-motor neuropathy, neuropathy, cerebellar degeneration and gastrointestinal pseudo-obstruction. . $^{5}$

The production of HU antigens by SCLC is not fully understood. In normal tissues, HU antigen production is restricted to the tissues of the nervous system. This antigen is found in the majority of SCLC cases. Although the neuroendocrine origin of SCLC is widely accepted, only $50 \%$ of neuroblastomas and very few neuroendocrine tumours express the HU antigen. $^{7}$

We have presented the case of a patient with chronic intestinal pseudo-obstruction as the first sign of his cancer. Pseudo-obstruction is defined as recurrent or persistent episodes of obstructed bowel symptoms in the absence of any mechanical obstruction. In the majority of reported cases, this complication is associated with SCLC and thymoma.

Nguyen-tat et al. detected in 1 patient, four months earlier of the diagnosis of SCLC, a symptomatic paraneoplastic gastroparesis with high anti-HU antibody titres. ${ }^{3}$

Our patient was anti-HU antibody positive and the finding of high anti-HU antibody titres suggests a clear influence of these antibodies on the development of our patient's disease. However, low titres have been detected in $16 \%$ of patients with SCLC without paraneoplastic syndrome. ${ }^{8}$ These antibodies exhibit reactivity against mesenteric plexus neurons producing inflammatory changes at these levels. ${ }^{9}$

The average time between the development of neurological paraneoplastic syndromes and diagnosis of cancer is four months; ${ }^{1-3}$ in our case, there was a gap of four and a half months between the onset of symptoms and the histological diagnosis.

Based on the assumption that paraneoplastic neuropathies are autoimmune disorders, several studies have been carried out with steroids, immuno-suppressants and even plasmapheresis, but with no clinical benefit being found. ${ }^{3-10-11}$ These syndromes improve with treatment of the underlying disease, as seen in our patient, who stopped having episodes of intestinal pseudo-obstruction after administration of chemotherapy.

Clinicians should consider paraneoplastic neuropathies, as chronic intestinal pseudo-obstruction, as a differential diagnosis for gastrointestinal dysmotility. Identification of paraneoplastic gastroparesis can lead to earlier diagnosis of a malignancy, and, in some cases, better prognosis.

\section{Conflict of interest}

The authors declare that they have no conflicts of interest. The authors alone are responsible for the content and writing of the paper.

\section{References}

1. Dalmau J, Graus F, Rosenblum MK, Posner JB. Anti-Hu--associated paraneoplastic encephalomyeli- 
tis/sensory neuronopathy. A clinical study of 71 patients. Medicine (Baltimore). 1992;71:59-72.

2. Jun S, Dimyan M, Jones KD, Ladabaum U. Obstipation as a paraneoplastic of small cell lung cancer: case report and literature review. Neurogastroenterology Motil. 2005;17:16-22.

3. Nguyen-tat M, Pohl J, Günter E, et al. Severe paraneoplastic gastroparesis associated with anti-Hu antibodies preceding the manifestation of small-cell lung cancer. Z Gastroenterol. 2008;46:274-8.

4. Abeloff M, Armitage J, Niederhuber J, et al. Síndromes Neurológicos paraneoplásicos. Oncología Clínica. 2005; 1:993.

5. Heidenreich F, Schober R, Brinck U, Hartung HP. Multiple paraneoplastic syndromes in a patient with antibodies to neuronal nucleoproteins (anti-Hu). J Neurol. 1995;242:210-6.

6. Cuillerier E, Coffin B, Potet F, et al. Paraneoplastic intestinal pseudo-obstruction revealing small cell lung carcinoma: "the anti-Hu syndrome". Gastroenterol Clin Biol. 1998; 22: 346-8.
7. Dalmau J, Furneaux HM, Cordon-Cardo C, Posner JB. The expression of the Hu (paraneoplastic encephalomyelitis/sensory neuronopathy) antigen in human normal and tumor tissues. Am J Pathol. 1992;141:881-6.

8. Lennon VA, Sas DF, Busk MF, Scheithauer B. Enteric neuronal antibodies in pseudoobstruction with small-cell lung carcinoma. Gastroenterology. 1991;100:137-42.

9. Altermatt HJ, Rodriguez M, Scheithauer B, Lennon VA. Paraneoplastic anti-Purkinje and type 1 anti-neuronal autoantibodies bind selectively to central peripheral and autonomic nervous system cells. Lab Invest. 1991; 65:412-20.

10. Thirkill CE, FitzGerald P, Sergutt RC. Cancer-associated retinopathy (CAR syndrome) with antibodies reacting with retinal, optic nerve and cancer cells. N England Journal of Medicine. 1989; 321: 1589-94.

11. Bell CE, Seetharam S. Expression of endodermally derived and neural crest-derived differentiation antigens by human lung and colon tumors. Cancer. 1979; 44:13-8. 